\title{
Nicotine Dependence
}

National Cancer Institute

\section{Source}

National Cancer Institute. Nicotine Dependence. NCI Thesaurus. Code C54203.

Physical and psychological dependence on nicotine. 